\title{
Posztszocialista jóllét és területi egyenlőtlenség a Kárpát-medencében
}

\author{
Post-socialist well-being and spatial inequalities in the \\ Carpathian Basin
}

\author{
SZIRMAI VIKTÓRIA, SCHUCHMANN JÚLIA, HALÁSZ LEVENTE
}

\begin{abstract}
SZIRMAI Viktória: kutatóprofesszor, MTA Társadalomtudományi Kutatóközpont, Szociológiai Intézet; 1014 Budapest, Úri utca 49.; tanszékvezető egyetemi tanár, Kodolányi János Főiskola, Európai Város és Regionális Tanulmányok Intézeti Tanszék, 1139 Budapest, Frangepán u. 50-56.; szirmai.viktoria@tk.mta.hu

SCHUCHMANN Júlia: főiskolai adjunktus, Kodolányi János Főiskola, Kulturális, Kommunikáció- és Médiatudományi Intézet, 1139 Budapest, Frangepán u. 50-56.; tudományos segédmunkatárs, MTA Közgazdaság- és Regionális Tudományi Kutatóközpont, Regionális Kutatások Intézete; 9022 Győr, Liszt Ferenc utca 10.; s.juliet82@gmail.com

HALÁSZ Levente: tudományos munkatárs, Kodolányi János Főiskola, Európai Város- és Regionális Tudományi Intézeti Tanszék; 1139 Budapest, Frangepán u. 50-56.; doktorjelölt, ELTE TTK Földtudományi Doktori Iskola; 1117 Budapest, Pázmány Péter sétány 1/c.; halaszlevente@hotmail.com
\end{abstract}

KULCSSZAVAK: egyenlőtlenségek; társadalmi jóllét; posztszocialista fejlődés, stiglitzi dimenziók

ABSZTRAKT: A tanulmány a Kárpát-medence térségeinek a társadalmi jólléttel összefüggő problémáit és területi egyenlőtlenségeit elemzi, részben társadalomstatisztikai módszerekkel, részben a kapcsolódó szakirodalom segítségével: országos és regionális léptékben, mégpedig hét magyar, négy szlovák, három román, egy szerb, egy ukrán, valamint a nyugati modellekkel való összehasonlítás szempontjának a biztosítása miatt egy osztrák NUTS 2 szintű régió eseteiben. A megalapozó kutatás a társadalmi jóllét stiglitzi dimenzióiból kiindulva néhány lényeges társadalmi jellegű mutatót vizsgál: a jövedelmet, az anyagi deprivációs szinteket, a szegénységi kockázatokat, az iskolázottságot, a munkanélküliséget, az egészséget, emellett a GDP és néhány társadalmi mutató kapcsolatát, valamint a térbeli társadalmi egyenlőtlenségeket. Az eredményeket rangsorolja, tipizálja, egyszersmind keresi a különböző régiók közötti hasonlóságokat és a különbségeket is.

Viktória SZIRMAI: research professor, Institute for Sociology, Centre for Social Sciences, Hungarian Academy of Sciences; Úri utca 49., H-1014 Budapest, Hungary; head of department, Institutional Department of European Urban and Regional Studies, Kodolányi János University of Applied Sciences; Frangepán u. 50-56., H-1139 Budapest; szirmai.viktoria@tk.mta.hu

Júlia SCHUCHMANN: college senior lecturer, Institute of Cultural, Communication and Media Studies, Kodolányi János University of Applied Sciences; Frangepán u. 50-56., H-1139 Budapest, Hungary; research fellow, Institute for Regional Studies, Centre for Economic and Regional Studies,

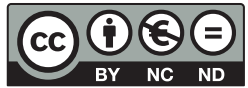


Hungarian Academy of Sciences; Liszt Ferenc u. 10., H-9022 Györ, Hungary; s.juliet82@gmail.com Levente HALÁSZ: research fellow, Institutional Department of European Urban and Regional Studies, Kodolányi János University of Applied Sciences; Frangepán u. 50-56., H-1139 Budapest, Hungary; PhD candidate, Doctoral School of Earth Sciences, Faculty of Sciences, Eötvös Loránd University; Pázmány Péter sétány 1/c., H-1117 Budapest, Hungary; halaszlevente@hotmail.com

KEYWORDS: inequalities; social well-being; Stiglitz dimensions; post-socialist development

ABSTRACT: This study analyzes the spatial inequality patterns of the Carpathian Basin in light of social well-being and based on social statistical methods conducted on the findings of relevant scientific literature. The investigation was carried on within national and regional contexts, examining seven Hungarian, four Slovakian, three Romanian, one Serbian, one Ukrainian, and, lastly, one Austrian NUTS 2 regions (the last one also allowing the comparison with Western European social, economic and spatial models). The empirical research aims are comprised of the so-called Stiglitz dimensions of social well-being: income, deprivation, risk of poverty, educational attainment, unemployment, health and, furthermore, some important dimensions of socio-spatial inequality. Within the confines of the study, we expressed each dimension by its most characteristic indicator and used the results to rank and typify the Carpathian Basin regions to look for similarities and differences between them.

The results back the well-known Western/Eastern or, even more, Western/Southeastern development slope concerning all the examined indicators. Burgenland, Western Slovakia, Western Hungary and the Budapest Agglomeration emerge out as the most developed areas of the Carpathian Basin, thanks to their localization (i.e. closeness to the European Union's 'centers'), their economic strength, and the diversity of their $R+D+I$ facilities. The Eastern regions - and in particular the Serbian and Ukrainian areas - on the other hand, are lagging behind in terms of social and economic progress. Shedding light on both inter- and intraregional disparities, our study highlights dichotomies between urban-rural, Western-Eastern, and advantageous and disadvantageous (i.e. pertaining to their accessibility, e.g. distance from motorway, from the capital, from the nearest regional hub, etc.) dimensions. Moreover, there are particular regions (e.g. deindustrialized crises areas, regions characterized by a high proportion of low-income strata and Roma minority, or territories with vast agricultural lands), where any development attempts aiming to improve social well-being so far has been futile. We also verified our diverse empirical investigations by spatial autocorrelation: while the socio-economic attributes of the most developed regions unambiguously show convergence and decreasing inequality, within and between the underdeveloped regions the same indicators present a backward convergence with slow and hindered socio-economic progress. This finding demonstrates that apart from the different region-types' convergent processes, inequality increases throughout the Carpathian Basin also in an absolute term.

\section{Bevezetés}

A társadalomtudományi gondolkodás egy új paradigmája szerint a mai folyamatok megértéséhez már nem elegendőek a kizárólag gazdasági szemléletű elemzések. A gazdaság, a gazdasági folyamatok mechanizmusai mellett a társadalmi tényezőket, az emberek mindennapi életviszonyait, közte a jóllétét is vizsgálni kell. Ezekre is figyelemmel kell lenni, akár a világban zajló jelenségek értelmezésekor, akár a legkülönbözőbb típusú fejlesztési célok kijelölésekor, akár a társadalmi és gazdasági, politikai problémák, feszültségek kiküszöbölésé- 
re törekedve (Dogan 2004; Horváth 2015c; Kolossov, Loughlin 2004). Ezt állítja a Stiglitz-jelentés is, amely a Columbia Egyetem professzora, a Nobel-díjas Joseph E. Stiglitz vezetésével, nemzetközileg ismert és elismert közgazdászok, társadalomkutatók részvételével készült 2009-ben (Stiglitz, Sen, Fitoussi 2009). A Report by the Commission on the Measurement of Economic Performance and Social Progress (A gazdasági teljesítményt és a társadalmi fejlődést mérő bizottság jelentése) címü tanulmánynak központi gondolata, hogy a termelés- és a gazdaságorientált mérésekről a mai és a jövőbeni generációk társadalmi jóllétére, annak vizsgálatára kell a hangsúlyokat helyezni. Főként azért, mert a világban hatalmas méretű, közte kiemelten jövedelmi egyenlőtlenségek, jólléti differenciáltságok jöttek létre, amelyek az országok versenyképességét, a gazdaság dinamizmusát rontják, a társadalmak mindennapi életviszonyait pedig kedvezőtlenül befolyásolják. Joseph E. Stiglitz 2012-ben megjelent The price of inequality: How today's divided society endangers our future (Az egyenlőtlenség ára: A mai megosztott társadalom miként veszélyezteti a jövőnket?) címü munkájában egyértelmüen leszögezi, hogy a „túlzott egyenlőtlenség árt a termelékenységnek és lassítja a fejlődést” (Stiglitz 2012). Az amerikai közgazdász erőteljesen bírálja az amerikai jövedelmi és egyéb gazdasági tényezőkből álló egyenlőtlenségi rendszert, ahol az amerikaiak egy százaléka kontrollálja a nemzeti vagyon 40 százalékát, ahol ez a felső egy százalék élvezi a legjobb egészségügyi ellátást, a legjobb oktatást és a vagyon előnyeit, miközben a többi 99 százalék mindebből kimarad. A vagyoni koncentrációt nem csupán az amerikai folyamatok mutatják: az adatok szerint a világ népességének fél százaléka birtokolja a gazdagság (a nettó vagyon) több mint harmadát (Credit Suisse 2014; inequality.org 2015). Egy másik adat szerint a leggazdagabbak egy százalékának tulajdonában áll a világ vagyonának közel fele (Credit Suisse 2014).

Ennek alapján jogos kérdés: mi történik a hasonló politikai, társadalmi, gazdasági berendezkedésű és jellegű kelet- és közép-európai térségekben, közte a Kárpát-medencei régiókban? Mi jellemző a vizsgált térség népességének jólléti mutatóira, illetve a térbeli társadalmi egyenlőtlenségek regionális szintű alakulására? Megfigyelhetőek-e hasonló koncentrációs folyamatok itt is, mint a fejlett nyugati modellek esetében? Tapasztalható-e felzárkózás, illetve közeledés a vizsgált különböző országok és régiók adatai között? Vagy éppen a diverzifikálódás, részben a közeledés, részben pedig a távolodás, a leszakadás a fő trend?

A tanulmány a válaszokat társadalomstatisztikai módszerek segítségével keresi: a Kárpát-medence posztszocialista országait és azok régióit (hét magyar, négy szlovák, három román, egy szerb, egy ukrán, valamint a nyugati modellekkel való összehasonlítás biztosítása miatt egy osztrák NUTS 2 szintű régiót ${ }^{1}$ ) elemzi. A Kárpát-medence - mint az elemzések földrajzi kerete - koherens gazdasági egységként létezett évszázadokon keresztül, amelynek országai történelmét, társadalmi és gazdasági folyamatait tekintve számos párhuzamosságot mutatnak. A tanulmány célja, hogy mind a hasonlóságokat, mind a főbb különbségeket bemutassa, azok ok-okozati összefüggéseit feltárja. A társadalmi jóllét stiglitzi dimenzióiból kiindulva néhány lényeges társadalmi jellegű muta- 
tót vizsgál: a jövedelmet, az anyagi deprivációs szinteket, a szegénységi kockázatokat, az iskolázottságot, a munkanélküliséget, az egészséget országos és regionális léptékekben, sőt rangsorolja, egyben tipizálja azokat. ${ }^{2}$

\section{A társadalmi térbeli különbségek történeti meghatározottságai}

A kelet-közép-európai rendszereket a szocializmusban a központosított, egypártrendszerre alapozott hatalmi berendezkedés, a redisztributív - vagyis a pénzügyi erőforrások újraelosztására épülő - társadalomirányítás mechanizmusai jellemezték. Ezek mellett a helyi (vállalati, területi) önállóság hiánya, a kizárólagos állami tulajdon, a negligált piaci viszonyok, a társadalmi részvétel, a civil szerveződések, mozgalmak kialakulatlansága, de nem utolsósorban a „puha” és a „kemény” diktatúra jellegzetességei között lavírozó, az egyének mindennapi életére rátelepedő, félelmet keltő pártállami jelenlét, a szólásszabadság hiánya is. A létező szocialista rendszerek hosszú ideig eltakarták, eltitkolták a különböző társadalmi problémákat és az egyenlőtlenségeket. A munkanélküliséget „kapun belül” tartották, a térbeli társadalmi polarizáció, a lakóhelyi szegregáció tényét vitatták, azt az új lakótelep-fejlesztésekkel, az egyformán kis lakások építésével akarták megoldani. A társadalmi egyenlőtlenségek eltussolását (közte az állampárt politikai, hatalmi céljainak pénzügyi bázisát) szolgálták a homogén munkabérek, a homogénnek mondott és vélt új ipari városfejlesztések, a sajtó és a média által közölt egytípusú ideológiák is. Természetesen a történelmi hasonlóságok mellett számos, a jóllétet befolyásoló különbség is megjelent. Elég csak a különutas jugoszláv szocializmusra gondolni, ahol már az 1950-es évektől Európa tőkés országai felé nyitottak, majd mind a KGST-vel, mind Nyugat-Európa kapitalista országaival kereskedtek. A '70-es évektől engedélyezték a külföldi (főként németországi, ausztriai) munkavállalást, így a hazautalások nagymértékben javították a lakosság jóllétének szintjét, biztosították megélhetését. Szintén megemlítendő a magyarországi ún. második gazdaság konjunktúrája és az ebből származó többletbevételek, amelyek nagyban hozzájárultak a „gulyáskommunizmus” kialakulásához, tehát a szocialista berendezkedés ellenére viszonylagos jóllét jellemezte az életszínvonalat. Úgyszintén különbözik Románia esete, ahol az 1980-as évekig egyértelműen növekedett a lakosság megelégedettségének szintje, nőttek a háztartások fogyasztásai, csökkent a város-vidék ellentét, azonban a Ceaușescu regnálásának utolsó tíz évét jellemző autarkiára törekvés, a külföldi kölcsönök visszafizetésének preferenciája aláásta a gazdasági fejlesztések és a társadalmi jóllét megerősítése irányába tett törekvéseket.

Az államszocialista rendszerek az európai típusú területi fejlődési folyamatokat is akadályozták, az erőltetett szocialista iparosítás koncepciója, az 
iparfejlesztések kiemelt előnyei, az infrastrukturális fejlesztések hátrányai a történelmi múlt, a korábbi időszakok területi egyenlőtlenségeit növelték: a városok és a vidéki térségek közötti társadalmi, gazdasági és infrastrukturális polarizáció szinte minden országban jellemző volt.

Az 1989-ben, 1990-ben kibontakozó társadalmi, politikai és gazdasági rendszerváltozás, a globalizáció, a külföldi működő tőke területválasztási stratégiái tovább élesítették a történetileg szerveződött területi szakadékokat. A külföldi működő tőkét, a multinacionális nagyvállalatokat a fejlett centrumtérségek, a regionálisan fejlettebb térségek nagyobb városai vonzották (Kiss 2015). Ezek máig is érvényes következményei: a gazdasági potenciál, valamint a különböző intézmények, szolgáltatások nagyvárosi koncentrációi, de a városcentrumok és a városi környékek, a különböző várostípusok közötti fejlettségbeli egyenlőtlenségek, a nagy és a kisebb városok, az ipari térségek, de fóként a nagyvárosi térségek és a vidéki területek közötti polarizációs folyamatok, sőt a területi szegregációs hatások is. Jellemző a szakképzett, magas jövedelmű társadalmi csoportok fejlettebb, a szakképzetlenebb, alacsony jövedelmű rétegek kedvezőtlenebb adottságú területi elhelyezkedése, a területi és a társadalmi hátrányok halmozódása.

A különböző kutatások szerint a kelet-közép-európai országok mindegyikében - közte a vizsgált Kárpát-medencei országokban is - a magas társadalmi státuszú, képzettebb, magasabb jövedelmű társadalmi csoportok inkább a városokban, nagyvárosokban (azok előkelőbb belvárosi negyedeiben), az alacsonyabb társadalmi státuszúak főként az ipari válságtérségekben, de elsősorban a hátrányos helyzetű vidéki falusi térségekben helyezkednek el (Gajdos 2008; Szirmai 2009, 2015; Timár, Kovács, Váradi 2015). A területi társadalmi elhelyezkedés folyamatai komoly hatással vannak (lehetnek) a társadalmi jóllét alakulására: a magyar nagyvárostérségi, illetve hátrányos helyzetű vidéki térségek kutatása szerint a területi és társadalmi jóllét-egyenlőtlenségi rendszerek között szignifikáns a kapcsolat. A társadalmi jóllét mért dimenziói követik a térbeli centrum-periféria modell hierarchikus fejlettségi szintjeit, a jóllét a legmagasabb a nagyobb városokban (azok belvárosaiban) és legkedvezőtlenebb a vidéki térségekben (lásd részletesen Szirmai 2015).

\section{A társadalmi jóllét differenciáltságai a Kárpát-medence régióiban}

\section{A jövedelemi egyenlötlenségek}

A kelet- és kelet-közép-európai országokban az 1989-es évben, illetve az 1990-es évek elején kezdődött társadalmi, politikai és gazdasági rendszerváltozás, a pi- 
acgazdaság kialakulása, az európai uniós csatlakozás és az annak előkészítésével is összefüggő támogatási rendszerek (Szerbia és Ukrajna kivételt képez) megteremtették a gazdasági és jövedelmi felzárkózás lehetőségeit. A reálfolyamatok azonban csupán részleges eredményeket hoztak: a felzárkózás a várakozásokhoz képest lényegesen lassabban és igen nagy különbségekkel játszódott le. A legfrissebb kutatások szerint például Szlovákia, de Lengyelország is sokkal sikeresebben valósította meg a jövedelmi felzárkózást, mint Magyarország vagy Románia. Többek között ezt bizonyítja, hogy a háztartási jövedelmek 2005 és 2013 között a leggyorsabban Szlovákiában és a legkevésbé Magyarországon nőttek (Szivós 2014).

Ezeket a különbségeket a történeti és gazdasági adottságok (közte a GDP) eltérései, az urbanizációs jellegzetességek, a globalizációs folyamatok hatásai, az azokhoz való adaptációs sajátosságok, a termelékenységi, valamint foglalkoztatottsági tényezők, az Európai Unióhoz tartozás, illetve a csatlakozás időpontjai (az azzal összefüggő várakozások), végül, de nem utolsósorban az európai kohéziós politikák működési zavarai okozzák. Jóllehet az Európai Unió számos olyan stratégiai döntést hozott, amelyek a területi egyenlőtlenségek enyhítését célozták, ezek azonban többnyire sikertelenek voltak (Horváth 2004, 2015c). Az Európai Bizottság kohéziós jelentései (például az 1996-os és 2004es) több ízben is megállapítják, hogy a strukturális politikai intézkedések ellenére a régiók közötti különbségek lényegében változatlanok maradtak (Horváth 2004).

1990 után a piacgazdasági átmenet, majd a globális gazdasági hatások erősödése a vizsgált posztszocialista országokban (és Ausztriában is) felerősítették a jövedelmi egyenlőtlenségeket. Éleződtek a különbségek a globális gazdaságból, a modernizációból profitálók és az abból kimaradók között (Medgyesi, Tóth 2012).

Az 1. ábra tanúsága szerint az átlagos nettó jövedelmek színvonala jól tükrözi a vizsgált országok közötti fejlettségbeli differenciákat és a lemaradás mértékeit. ${ }^{3}$ A vizsgált országokban az átlagos nettó jövedelmek különböző mértékben bár, de elmaradnak mind az uniós átlagtól, mind pedig a fejlett Ausztria jövedelemszintjétől. Románia és Szerbia nettó jövedelemszintje csupán töredéke az uniós átlagnak, de még a szlovák vagy a magyar helyzet sem mutat lényegesen kedvezőbb képet.

2009 és 2012 között Magyarországon is jelentősen nőttek a jövedelmi egyenlőtlenségek. Az egy főre jutó jövedelmek legfelső és legalsó jövedelmi deciliseinek aránya 7,2-ről 9,0-ra emelkedett. Eközben a legalsó tized részesedése az összes jövedelemből 3,1\%-ról 2,5\%-ra csökkent, a legfelső decilis részesedése - jóllehet nem nagy mértékben, de - növekedett. A jövedelemeloszlást jellemző valamennyi mutató (közte a Gini-együttható) növekedést jelzett. A magyar társadalomban több szempontból is polarizációs folyamat zajlik. Az utóbbi években a felsőbb társadalmi szegmensbe tartozók száma, aránya jelentősen csökkent, a középosztály leszakadása pedig erősödött, mind a mai napig nem alakult ki a modernizáció 
1. ábra: Az: átlagos nettó jövedelmek az Európai Unióban és a vizsgált országokban (2014, euró) Average net income in the $\mathrm{EU}$ and in the analyzed countries (2014; euro)

2500

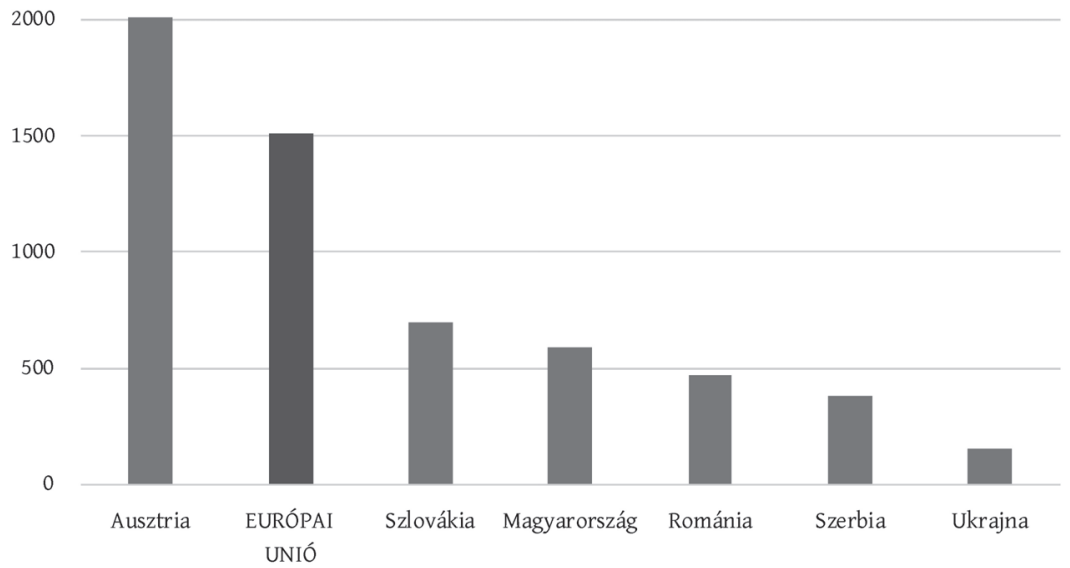

Adatok forrása: Eurostat.

szempontjából létfontosságú széles középosztály, miközben a szegények aránya növekedett (Kolosi 2000; Osztálylétszám 2014).

Fontos megemlíteni a vizsgált összes posztszocialista állam (kivéve Ausztria) esetében a külföldi munkavállalás jelentőségének növekedését, amely enyhít(het)i az adott ország kedvezőtlen jövedelmi, megélhetési helyzetét. Legnagyobb arányban Romániából költöztek nyugatabbi országokba magasabb jövedelmek, jobb társadalmi presztízs reményében, ezzel egy időben súlyosbodó demográfiai krízist okozva a román ellátórendszereknek. Jelenleg a románok 12\%-a (azaz 3 millió fö) dolgozik az ország határain kívül, ez az érték az Európai Unió tagállamai közül Bulgáriával egyetemben listavezető (Dewsbury 2012). A magyar, szlovákiai és szerbiai eset hasonló, évről évre növekvő számban hagyják el munkavállalás céljából ideiglenesen vagy örökre az országokat. Magyarországról 1989 óta 450000 fő (a lakosság 4,5\%-a), Szlovákiából 250000 fó (a lakosság 4,6\%-a), míg Szerbiából 313000 fő (a szerbiai lakosság 4,2\%-a) költözött el hazájából (InSerbia Network Foundation 2015; Minarechová 2015; Zsuppán 2013). (Az ukránok külföldi munkavállalásának számszerüsítése az országot sújtó háborús konfliktus, a nagyszámú országon belüli és országot elhagyni kényszerülő menekült miatt lehetetlen feladat.)

Kutatások bizonyítják, hogy a kivándorlás elsősorban a fiatalokat, a diplomásokat érinti, ők azok, akik a legnagyobb arányban vesznek részt a nyugatra irányuló migrációban, ez egyértelmüen az anyaország vesztesége, amely gyengíti ezeknek az országoknak a gazdasági versenyképességét (Blaskó, Gödri 2016; Hárs 2012; Sik, Szeitl 2016). Habár országos szinten negatív folyamattal állunk 
szemben, egyéni, családi szinten változatos képet kapunk, ha a hazautalások GDP-hez viszonyított arányát vizsgáljuk. Legnagyobb összeget a külföldi szerb és ukrán munkavállalók utalnak haza (a szerbiai GDP 9,2\%-a, az ukrán 6,5\%-a). Magyarországon (3,3\%), Szlovákiában (2,5\%) és Romániában $(1,8 \%)$ is jelentős bevételi forrást jelentenek ezen összegek, így kisebb-nagyobb mértékben javítják a kedvezőtlen országos, illetve regionális statisztikák alapján vázolt képet.

\section{Az anyagi depriváció problémái}

A deprivációs index ${ }^{4}$ eredményei szerint jelentős különbségek feszülnek az Európai Unió fejlett centrumtérségei és a (fél)perifériák között. A 2014-es adatok alapján a depriváltak arányaiban négy csoport különíthető el. Az első Ausztria 3,6\%-os aránnyal. A második csoport (az Európai Unió teljes lakosságának körében mért 9,1\%-os arányt meghaladó) Szlovákia, ahol a vizsgált érték 9,9\%. A harmadik csoportba került Magyarország, Románia és Szerbia (ez utóbbi esetben a deprivációs index az Európai Unió értékének 2,5-szerese). Ukrajna negyedikként a legrosszabb mutatóval bíró ország, itt a teljes lakosság 35,5\%-a él anyagi nélkülözések közepette.

2. ábra: A deprivációs index értékei a Kárpát-medence régióiban (2014,\%)

Regions of the Carpathian Basin according to their deprivation index (2014; \%)

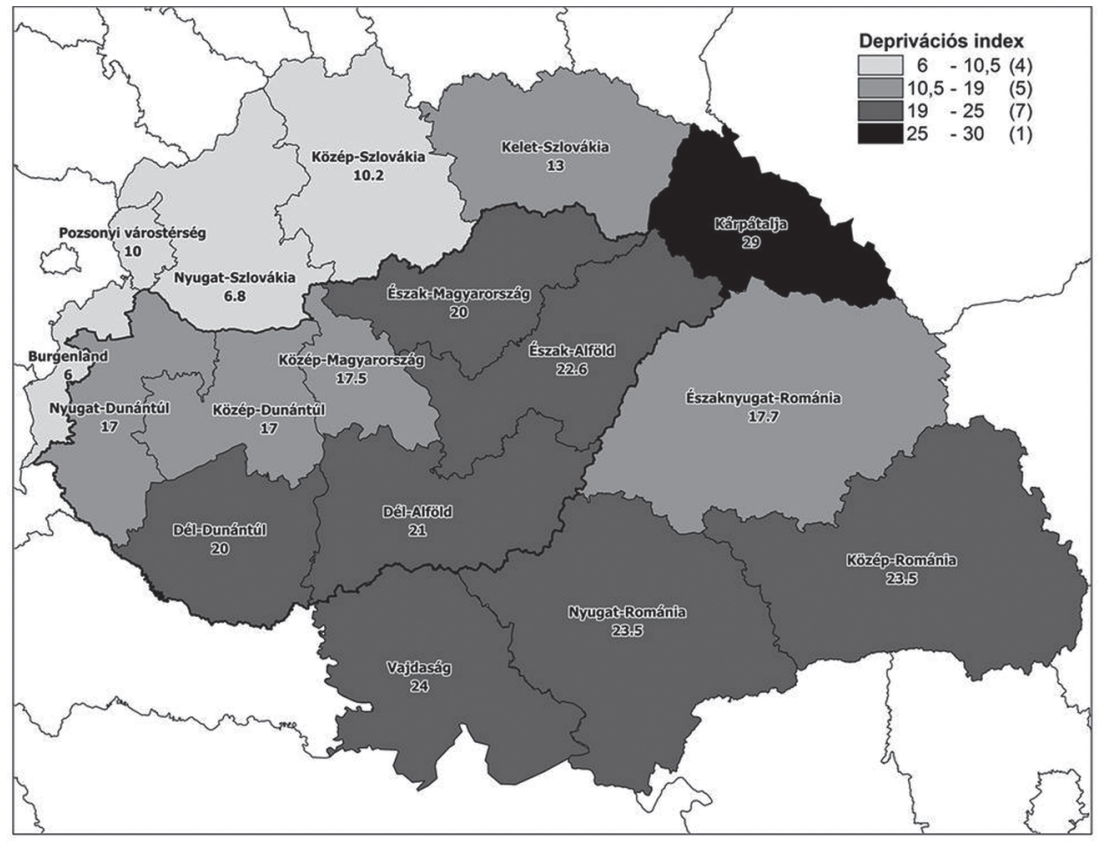

Készitette: Szélpál Melinda Eurostat- és Világbank-adatok alapján. 
A depriváltak arányának regionális különbségei kissé más képet mutatnak: a vizsgált régiók öt csoportja különíthető el. Az első csoportban a depriváltak aránya az európai uniós átlag alatt marad: ide tartozik az osztrák Burgenland (6\%) és Nyugat-Szlovákia (6,8\%). A második csoport deprivációs indexeinek értéke az uniós átlaggal közel megegyezik, mint például a Pozsonyi várostérség (10\%) és Közép-Szlovákia (10,2\%). A harmadik csoport négy régiójának indexértéke már meghaladja az előbbieket és alacsonyabb 17\%-nál. Ebben található a gazdaságilag kevésbé fejlett és társadalmi problémákkal érintett Kelet-Szlovákia és három magyar régió: Közép-Dunántúl, Nyugat-Dunántúl és Közép-Magyarország. A negyedik csoportban a depriváltak aránya már az uniós átlag duplája (17 és 20\% közötti). Ebben a csoportban egy román régió (Északnyugat-Románia) mellett három kelet-magyarországi régió is megtalálható. Az utolsó, ötödik régiócsoportban a nagyon magas, $20 \%$ feletti deprivációs értékekkel rendelkező régiók vannak: az Észak-alföldi régió, valamint két román (Nyugat- és Közép-Románia), a szerb Vajdaság és Kárpátalja (2. ábra).

\section{A szegénység jellemzői}

A Kárpát-medence régióiban a szegénység területi mintázata nagyjából, de nem egyértelmủen korrelál a gazdasági fejlettséggel. Leginkább a rurális térségekben, a belső perifériákon, az ipari válságövezetekben, a magas arányban deprivált lakossággal és kisebbségi csoporthoz tartozóval (pl. romák) jellemezhető térségekben idült probléma. A nyugat-keleti lejtő, valamint a centrum-periféria reláció érvényesül, ennek értelmében az elhanyagolható társadalmi-gazdasági különbségekkel rendelkező Ausztriában, valamint Szlovákia és Magyarország nyugati térségeiben legkedvezőbb a helyzet, azaz uniós átlag alatti a szegénységi kockázatban élők, a depriváltak, a relatív és/vagy abszolút szegények aránya. Kelet, délkelet felé haladva egyre súlyosabb gondot okoz a szegénység, Nyugat-Románia lakosságának csaknem negyede, míg az elmaradott kelet- és északkelet-magyarországi társadalmak 26-29\%-a él szegénységi kockázatban. A vajdasági helyzet az uniós átlag alatti szerb állapotokhoz képest kedvezőbb, viszont a kárpátaljai lakosság gyorsan romló tendenciájú és tartósan fennálló elszegényedése példa nélküli a vizsgált makrotérségben. A témakör mélyebb feltárása érdekében az emberi szegénységi mutatót ${ }^{5}$ elemeztük (3. ábra). A komplex indikátor alapján az Európai Unió átlagához, illetve egymáshoz viszonyítva négy régiócsoport különíthető el. Az európai uniós érték alatti, legalacsonyabb humán szegénységi mutatókkal a pozsonyi és nyugat-szlovákiai régiók, majd Burgenland és Közép-Magyarország, illetve Közép- és Kelet-Szlovákia jellemezhetőek. Ez is bizonyítja, hogy a szlovák felzárkóztatási programok sikerrel végződtek, ugyanis látványos különbségek a lakosság elszegényedése, a szegények aránya terén nem érzékelhetők. Az uniós átlaggal megegyező vagy ahhoz közelítő második csoportba került a két ro- 
3. ábra: Az emberi szegénységi mutató a vizsgált Kárpát-medencei régiókban (2011,\%) Human Poverty Index in the analyzed regions (2011;\%)

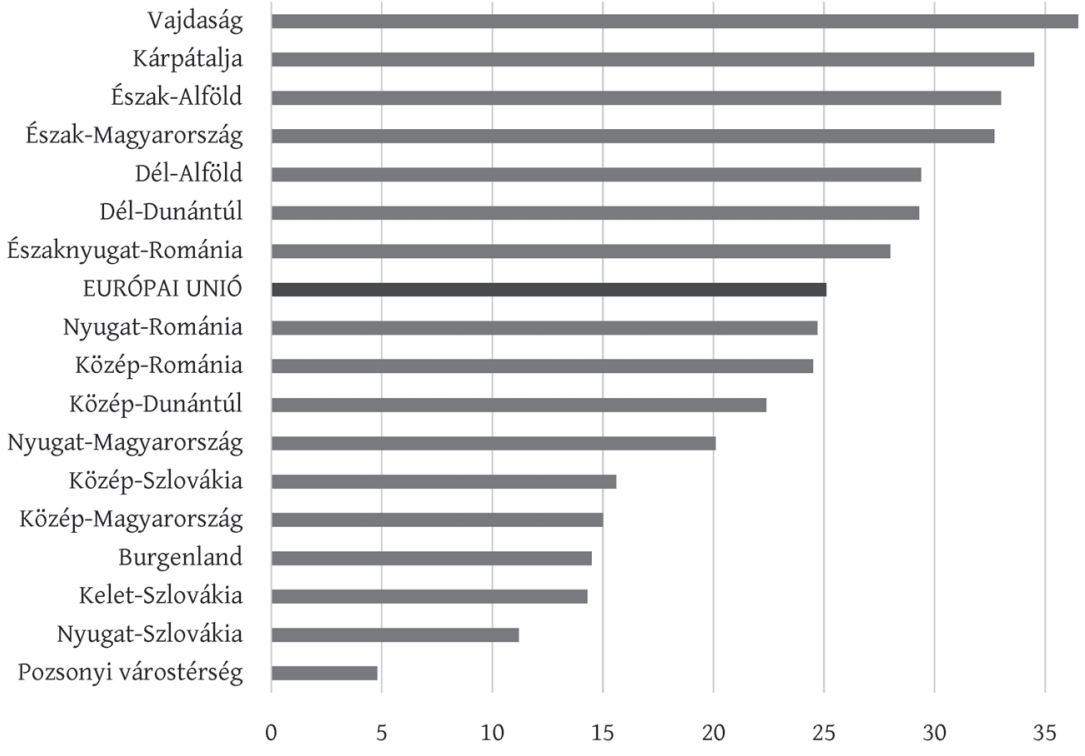

Adatok forrása: Eurostat, Knoema.

mániai régió (Nyugat- és Közép-Románia), Közép-Dunántúl és Nyugat-Dunántúl. A többi vizsgált Kárpát-medencei régióban (egy román és a többi magyar régió eseteiben) a mutató értékei az uniós átlagot meghaladják. Ez az érték a legmagasabb az Észak-alföldi és az Észak-magyarországi régiókban, a Vajdaságban és Kárpátalján.

\section{Az iskolázottság egyenlötlenségei}

A társadalmi haladásnak, egy ország fejlettségének, társadalmi versenyképességének lényeges feltétele a felsőfokú végzettséggel rendelkezők aránya. 2015-ben az EU 28 tagállamában a 30-34 éves korosztály 38,7\%-a rendelkezett diplomával. Ausztria értékei megegyeznek az EU-s átlaggal, ezt követi Magyarország (34,3\%), majd Szlovákia (28,4\%). Az EU-s átlagtól jelentősen elmaradnak a román (25,6\%) és a csatlakozásra váró szerb (23\%), valamint az ukrán (22\%) adatok. Ha regionális összehasonlításban nézzük, akkor az európai uniós átlagot csak két metropolisztérség (a pozsonyi és a közép-magyarországi) értékei haladják meg.

A diplomások arányának regionális differenciáltságaiban szintén négy nagy csoport különíthető el (4. ábra): az első az EU-átlagnál is jobb diplomás arányú térségek (Pozsony, Közép-Magyarország), ahol az adott ország felsőoktatási intézményeinek több mint fele található. A második csoportban az EU át- 
4. ábra: A felsőfokú végzettséggel rendelkezők aránya a 25-64 éves korosztályban (2015,\%)

Proportion of 25-64 year-olds having a diploma or other equivalent HEI certificate (2015; \%)

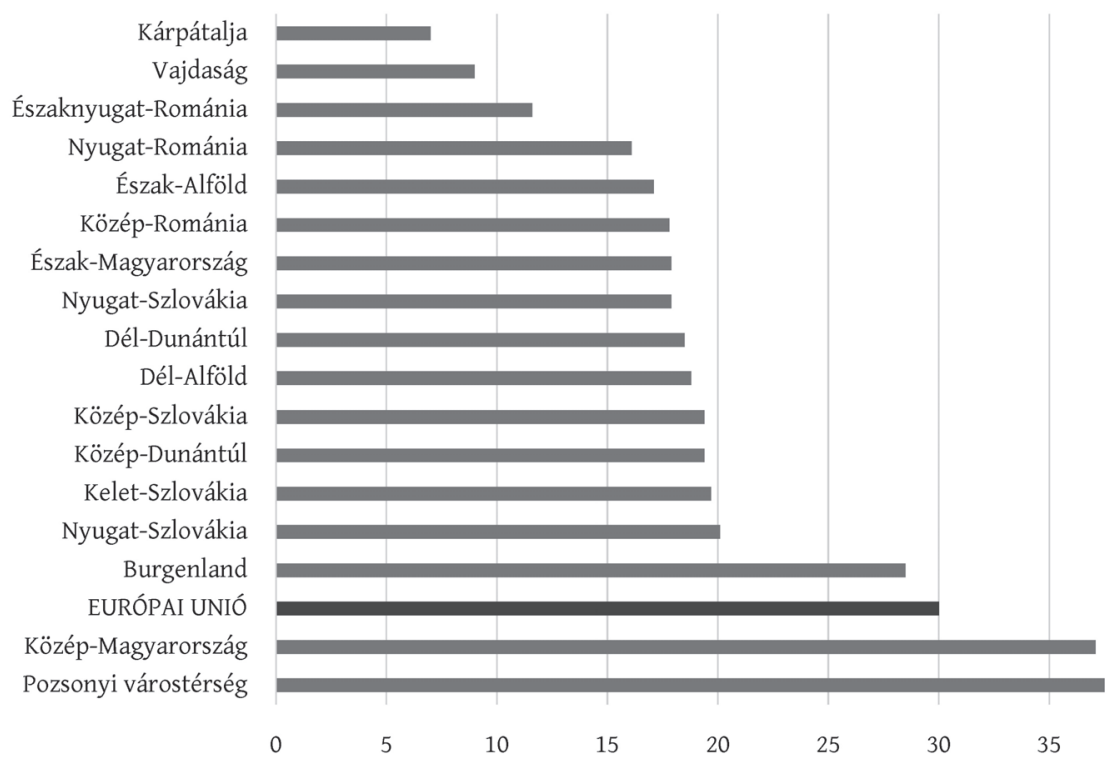

Adatok forrása: Eurostat, Knoema.

lagával megegyező értékkel Burgenland található. A harmadik csoport a Nyugat-Dunántúltól az Észak-Alföldig terjed. A negyedik csoportot a Kárpát-medence leginkább leszakadó térségei alkotják.

A középmezőny kiegyenlítettsége akár meglepő is lehet, hiszen a térségek gazdasági adottságai igen eltérőek, számos esetben kifejezetten fejletlen térségekkel. A magyarázatot a magas szintű kutatás-fejlesztési potenciál, az oktatási és kutatási intézmények jelenléte adja. Példa lehet erre a gazdasági és társadalmi problémákkal, közte magas munkanélküliséggel is sújtott Kelet-Szlovákia, ahol számos kutatóintézet müködik: közte a Szlovák Tudományos Akadémia nyolc intézete, továbbá itt található a Kassai Egyetem, amely a szlovák felsőoktatás egyik központja 29,3 ezer hallgatójával (Horváth 2015b). Hasonló okokra vezethető vissza a diplomások „közepes” aránya a szintén súlyos gazdasági problémákkal küzdő és egyre inkább leszakadó Dél-alföldi régióban, ahol a Szegedi Tudományegyetem és a hozzá kapcsolódó kutatóhelyek adnak munkahelyet és megélhetést a diplomás, képzettebb társadalmi csoportoknak, de a nyugat-romániai régiók hasonló adatai mögött is a nagyvárosok (Nagyvárad, Kolozsvár, Temesvár, Szatmárnémeti rangos felsőoktatási intézményei és K+F+Iegységei állnak.

A szerbiai Vajdaságban és Kárpátalján legalacsonyabb a diplomások aránya: az érték meg sem közelíti az európai uniós átlagot, noha Vajdaságban koncentrálódik a legtöbb diplomás a belgrádi régió után (Horváth 2015b). 


\section{A munkanélküliség problémái}

A munkanélküliség országok szerinti sorrendje eltér a korábbi mutatók sorrendjétől. 2014-ben az Európai Unió munkanélküliségi rátája 10,2\% volt. Ennél alacsonyabb az érték Ausztriában: 5\%. Ez az osztrák gazdaság stabil működését mutatja. A szintén alacsonyabb román érték $(6,8 \%)$ magyarázata nem az ország fejlettsége, hanem éppen a fejletlensége, pontosabban a román állampolgárok növekvő arányú külföldi munkavállalása. Az uniós átlag alatti magyar munkanélküliségi ráta mögött szintén nem a gazdaság dinamizmusa, hanem a 2011-ben bevezetett közmunkaprogram ${ }^{6}$ található. A szlovák adat akár meglepő is lehet, kiváltképp, ha a korábbiakban leírt kedvező pozíciókra gondolunk. Szlovákia munkanélküliségi rátája az uniós átlag feletti, 13,2\%, ami a történeti okokon túl fóként az ország eurózónához való csatlakozását követő gazdasági visszaeséssel magyarázható. A két, unión kívüli országban az uniós átlag duplája, azaz 20\% feletti a munkanélküliségi ráta: Szerbiában $20 \%$ és Ukrajnában $23 \%$.

A munkanélküliségi ráta regionális jellemzői alapján négy régiócsoport különíthető el. Az első csoportban azok a régiók találhatóak, amelyekben a munkanélküliségi ráta különböző mértékben bár, de meghaladja az uniós átlagot. Ide három szlovák (Nyugat-, Közép- és Kelet-Szlovákia), egy szerb (Vajdaság), egy ukrán (Kárpátalja) és egy magyar régió (Észak-Alföld) tartozik. A második csoportba az uniós átlagnál csak néhány százalékkal alacsonyabb munkanélküliségi rátájú régiók kerültek (az Észak-magyarországi, a Dél-dunántúli, a Dél-alföldi régiók), valamint Nyugat- és Közép-Románia. A harmadik csoportban találni a két fővárosi régiót (a budapestit és a pozsonyit) valamint a Közép-dunántúli régiót. A negyedik csoportban a legalacsonyabb munkanélküliségủ rátával jellemezhető régiók, Nyugat-Dunántúl és Északnyugat-Románia találhatók.

\section{Az egészségi állapot egyenlötlenségei}

A vizsgált NUTS 2-es régiókban az egészségegyenlőtlenségek indikátorai (születéskor várható élettartam, nyers születési és halálozási arányszám, gyermekhalandóság, daganatos megbetegedések száma, alkohollal, droggal, dohányzással kapcsolatba hozható halálesetek száma, diabéteszben szenvedők száma stb.) alapján (5. ábra) egyértelműen kirajzolódik a nyugat-keleti lejtő, a centrum-periféria dichotómia, a városi és rurális terek közötti különbség (Berki, Halász 2015; Uzzoli 2006). A vizsgált térségek közül Burgenland szerepel a legelőkelőbb helyen. A régióban fejlett az egészségügyi ellátórendszer, az állam erős szociális hálója, számos jólléti beavatkozása következtében a gyermekhalandóság elhanyagolható, alacsony a nyers halálozási ráta értéke, azonban a születések száma a gyors ütemben elöregedő, alacsony gyermekvállalási kedvű európai lakosságra jellemző trendeket mutatja. Szlovákiában is egyértelműen látszik a nyugatkeleti ellentét. A fóváros környéki régió lakosságának születéskor várható élet- 
5. ábra: A születéskor várható élettartam a Kárpát-medence NUTS 2-es régióiban (2013, év) Life expectancy at birth in all NUTS 2 regions in the Carpathian Basin (2013; in year)

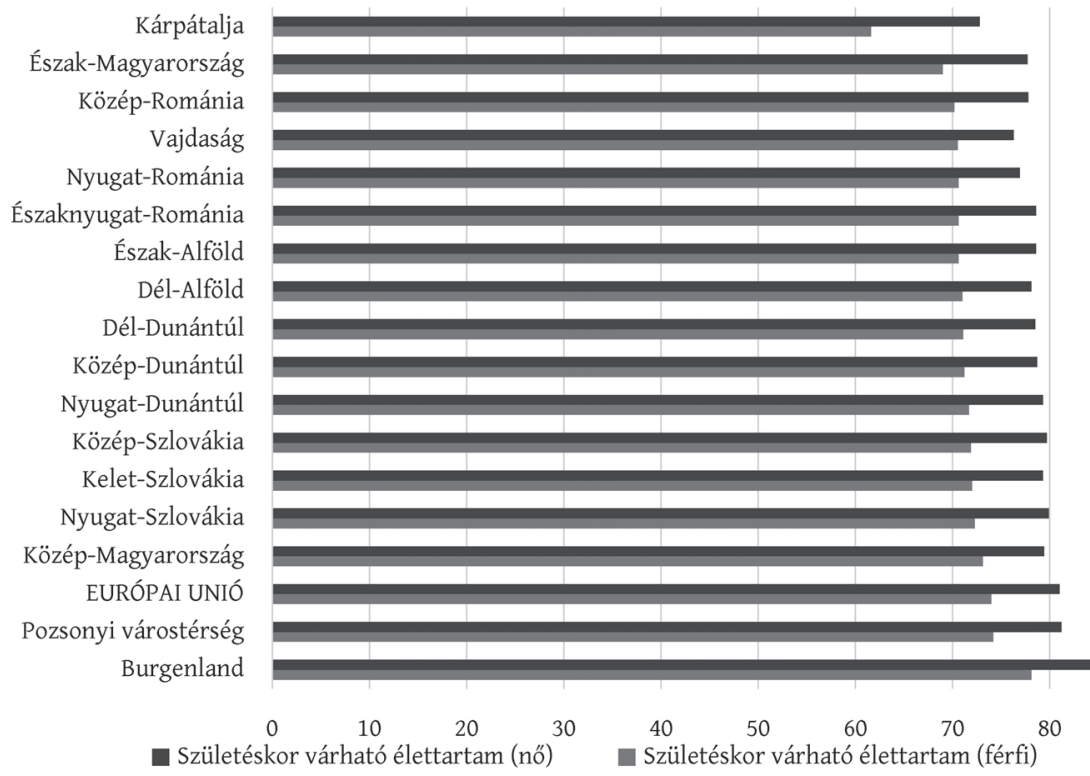

Adatok forrása: Világbank, Eurostat, Knoema.

tartama kiemelkedő (Rosicova et al. 2011), kedvező a mortalitási és morbiditási helyzet, amely az EU átlagánál is jobb. Ezzel szemben a többi szlovák régió lakosságának egészségi állapota kedvezőtlenebb, bár az országon belüli egészségegyenlőtlenségek nem kirívóak. A magyar régiók egészségegyenlőtlenségei terén egyértelmű a nyugat-kelet differencia - természetesen a Közép-magyarországi régió kivételt képez. A vizsgált térségek lakosságának születéskor várható élettartalma nagyjából azonos, csupán az észak-magyarországi térség marad el ettől látványosan. Itt az átlagos várható életkor egyrészt a legalacsonyabb, másrészt a férfiak és nők közötti különbség is növekszik. Ennek hátterében az elégtelen szociális helyzet, a dezindusztrializáció miatti megnövekedett munkanélküliség és kilátástalanság, a roma lakosság magas aránya, a számos település szegregátumaiban elégtelen higiéniás állapotok, a társadalmi devianciák egyre gyakoribb megjelenése, valamint az egészségkárosító életforma áll. Románia a várható élettartam tükrében az unión belül a sereghajtók közé tartozik. Közel 10 év a különbség az EU leghosszabb születéskor várható élettartamával rendelkező svéd (81,6 év) és ír (81 év), valamint a román (73,8 év) lakosság adatai között. Még aggasztóbb a kép, ha a regionális szinten vizsgálódunk; az ország fejlett és alulfejlett térségei között 2,1 év a különbség. Kárpátmedencei összehasonlításban így a román helyzet kifejezetten szomorú képet nyújt, ugyanis az ország gazdaságilag viszonylag fejlett nyugati régiói is az egészségügyi ranglétra legvégén helyezkednek el. Szerbiában a születéskor vár- 
ható élettartam 75 év, és itt a legkiélezettebbek az országon belüli egészségegyenlőtlenségek. A belgrádi városkörnyék mellett Vajdaság lakossága jellemezhető a legpozitívabb egészségi állapottal, és ez az egyetlen régió, ahol a népességszám természetes növekedéséhez megfelelő az egyensúly a születési és halálozási arányszámok között. A kedvező érték azonban elfedi az intraregionális szélsőségeket: ezt alátámasztja, hogy a nagyarányú roma népességgel rendelkező, rossz szociális körülmények között élő lakosság átlagosan csak 45 évig él. A kárpátaljai térségben a legrosszabb a helyzet, 67,2 év a születéskor várható élettartam, ezen felül itt a leglátványosabb a nők és férfiak közötti különbség. A helyzetet nagyban súlyosbítja a begyürüző és súlyosbodó gazdasági válság, az ukrán-orosz háború miatti kilátástalanság, a lakosság emigrációja, a férfiak (családfenntartók) sorozása, az elégtelen (köz)egészségügyi helyzet, a szociális háló megnyirbálása, az orvoshiány, a gyógyszerhiány, az alultápláltság és a rossz egészségmagatartás.

\section{A társadalmi jóllét regionális egyenlőtlenségrendszerei}

A társadalmi jóllét különböző dimenzióinak a vizsgálatából jól láthatóak a térbeli egyenlőtlenségek rendszerei: egyrészt az országos szintű, másrészt a belső regionális polarizáltság, főként a fejlettebb nyugati és a fejletlenebb keleti, délkeleti országrészek között, valamint a centrum és a periféria megosztottsága. A tanulmány által elemzett szlovák adatok, de a kapcsolódó szakirodalmak szerint is 1989 után éles területi társadalmi polarizáció jött létre az unió centrumtérségéhez legközelebbi, legnagyobb gazdasági súllyal bíró nyugati országrészei és a szegényebb délkeleti térségei között. Az északi, illetve nyugati urbanizáltabb, magasabb gazdasági, társadalmi és kulturális potenciállal bíró térségekhez képest jelentős mértékben marginalizálódtak (többek között a társadalmi kirekesztés hatásaira is) a déli és a keleti országrészek kevésbé urbanizáltabb részei, a kisebb falvak (Gajdos 2008).

A román adatok és a szakirodalmi elemzések hasonló trendekre mutatnak rá: az egalitariánus szocializmus homogén, egyben szegény társadalmat hozott létre (Precupetu, Precupetu 2013). A rendszerváltás, a dezinduszrializáció, a piaci társadalomra és gazdaságra való átállás, a reálbérek drasztikus csökkenése (ez 1996-ban az 1990-es bérszínvonal 56,2\%-a volt) tovább élezték az egyenlőtlenségeket: a mai Románia az Európai Unió legszegényebb országai között található (Precupetu, Preoteasa, Vlase 2015). A privatizáció, a korrupció nagy egyéni vagyonokat hozott egy kis létszámú elit számára. A mezőgazdasági privatizáció, a fragmentált kisbirtokok, az ipari átalakulás, a nagyvállalatok tönkremenetele miatt tömegek (különösképpen a fiatalok és az alacsony iskolai végzettséggel rendelkezők) váltak munkanélkülivé. (A munkanélküliségi ráta 1995-ben 9,5\% volt, 2011-ben 7,5\%.) A romániai vidéki szegénység mindig jóval magasabb volt, 
mint a városi szegénység, ezért is a vidéki népességből igen sokan indultak a nagyobb városok felé (legújabban külföldre). A város és a vidék közötti különbség folyamatosan mélyül (Precupetu, Precupetu 2013).

A szerb elemzésekből még súlyosabb egyenlőtlenségekre derült fény: a késleltetett rendszerváltás, a piaci viszonyok kiépülésének az elmaradottsága felerősítették a korábbi térbeli polarizáltságot, főként az ország északi és déli térségei, a városok és falvak között. A különbségek különösképpen 2001 és 2010 között erősödtek (Winkler 2012). A kedvezőtlen folyamatok (közte az alacsony GDP) föként a keleti országrészek periferikus térségeit sújtják (Mijačić, Paunović 2011).

Érdekes egyenlőtlenségi mintázatot sejtet Ukrajna. Itt nem mutatható ki a nyugat-keleti fejlettségi lejtő, ugyanis a többségében oroszok által lakott keletukrajnai térség - főként a nagyvárosi agglomerációi - jellemezhetőek a legkedvezőbb társadalmi és gazdasági mutatókkal (Karácsonyi, Mezentsev, Pidgrusnyi, Dövényi 2014). A globális pénzügyi válság azonban kiegyenlítő hatással bírt, mivel kifejezetten ezeken a térségeket érintette. Kárpátalja a közepesen fejlett ukrán rajonok csoportját gazdagítja, ahol a jelentősebb városok kiemelkedő gazdasági súllyal és viszonylag magas jólléttel, míg a (hegy)vidéki terek látványosabb elmaradottsággal jellemezhetőek. Az orosz-ukrán konfliktus általánosságban elszegényedést, kilátástalanságot és a legalsóbb jövedelmi decilisbe tartozók helyzetének egyértelmű romlását hozta.

A társadalmi jóllét különböző dimenzióinak a vizsgálatából a területi koncentráció trendjei is kiderülnek: a fejlett térségek fejlődésének dinamizálódása, a leszakadók növekvő hátrányai. A fejlett térségek között kiemelkedő a fővárosi terek előnyeinek fokozatos növekedése. A szlovák eseteket elemző munkákból jól látható Pozsony előnyös pozíciója az ország többi régiójához képest. Gajdos $(2005,2008)$ szerint ez a multinacionális cégeknek, Pozsony esetében például a Volkswagen fővárosi jelenlétének, gazdasági potenciált is növelő szerepének köszönhető. A román fővárosi térség, Bukarest gazdasági helyzete szintén jóval kedvezőbb, mint a keleti, az északkeleti, illetve a délkeleti régióké (Precupetu, Precupetu 2013). A magyar fövárosi térség hasonlóan kiemelkedő pozíciót foglal el: az országban megtermelt GDP közel 40\%-át itt állítják elő, az ország felsőoktatási hallgatóinak 60\%-a itt tanul. A magyar nagyvárosi térségeket elemző összehasonlító kutatások szerint 2005 és 2014 között erőteljesen növekedett a társadalmi és a gazdasági polarizáció a budapesti és a vidéki nagyvárostérségek között (Schuchmann, Váradi 2015). A fövároshoz képest a vidéki nagyvárosoknak nagyobb a népességvesztése, eröteljesebb az elvándorlás, részben a gazdaság korábbihoz képest is jelentősebb budapesti koncentrációja, részben a vidéki nagyvárosi szuburbanizációs folyamatok miatt (Schuchmann 2015). A budapesti térség munkanélküliségi rátája is kisebb, mint a vidéki nagyvárosoké. Horváth Gyula (2015a) véleménye szerint a nagyvárosok esetében regisztrált visszaesés rontja a globális versenyben való részvétel esélyeit. 


\section{Összegzés}

Ez a tanulmány a Kárpát-medence posztszocialista országainak, illetve az árnyaltabb eredmények végett NUTS 2-es térségeinek a jólléttel összefüggő problémáit és területi egyenlőtlenségeit elemezte. A cél annak a feltárása volt, hogy a kelet-közép-európai térség e sajátos gazdasági egységének népessége milyen jólléti viszonyok között él, illetve hogy a medence térségeit milyen egyenlőtlenségek szabdalják, és azokat hogyan befolyásolják a történeti örökségek, a szocialista rezsimek örökségei, a társadalmi és politikai rendszerváltás, a piacgazdaságra való áttérés.

A szakirodalmi elemzések alapján nyilvánvaló, hogy a Kárpát-medencében található államok számos jellemzője közös: hasonlóak fejlődéstörténeti sajátosságaik és hasonlóak a fejlett nyugat-európai országokhoz képest késleltetett társadalmi, gazdasági, urbanizációs fejlődési modell következményei is (Enyedi 2011). Továbbá a szocialista viszonyok közötti lét (az erős állami jelenlét, a piaci viszonyok hiánya) és annak máig tartó konzekvenciái, majd az 1989-ben, 1990-ben kibontakozott társadalmi, gazdasági és politikai rendszerváltások és azok hatásai is közösek. Hasonlóak az európai uniós csatlakozás, illetve annak az előkészületeivel kapcsolatos következmények, a globális gazdaságba történő integrációt követő mechanizmusok szintén. A megnövekedett társadalmi feszültségek, a jólléti problémák, az erős társadalmi, jövedelmi, képzettségi polarizáció, az elszegényedés, valamint a regionális egyenlőtlenségek is közös jellegzetességek.

Eközben nyilvánvalóak a különbségek: az egyes országok fejlődéstörténeti sajátosságai, a szocialista modellek szerveződésének, illetve érvényesülésének a specifikumai, az európai uniós csatlakozás időpontbeli különbségei (vagy az integráció várható időpontja Szerbia esetében), a globális tőke megjelenésének országos és regionális differenciái. A nemzetgazdaságok adottságai, a civil társadalmi jellemzők és a kulturális adottságok pedig sajátos fejlődési utakat, jellegzetes jólléti problémákat és területi egyenlőtlenségeket okoznak. A társadalomstatisztikai elemzésekből a következő jelentősebb trendek láthatóak:

1. Kiderültek az országok közötti hierarchikus különbségek: a fejlett, nyugati fejlődési modell szerinti osztrák régió szinte minden vizsgált dimenzió esetében érvényesülő általános fejlettségbeli előnyei, a többiek hátrányosabb pozíciói. Az osztrák régió adatait a szlovák, a magyar, a román, a szerb és végül az ukrán régiók követték.

2. Megnyilvánultak az egyes országok belső regionális sajátosságai, a történeti adottságok, a fejlődéstörténeti körülmények, a mai strukturális és egyéb mechanizmusok hatásai. Ezen belül világossá váltak a különböző országok azonos fejlettségi szintekkel rendelkező régiói esetében a közeledés jelei. Egyrészt a különböző országok fejlettebb régiói között hasonlóság tapasztalható: a vizsgált jólléti dimenziókban a különböző országok fejlettebb centrumtérségei (fővárosa és régióközpontjai), illetve az egyes országok fejlettebb (az EU-átlaghoz közeledő vagy azt meghaladó) nyugati térségei- 
nek az értékei (az általunk vizsgált időpontokban) hasonlítanak egymásra. Másrészt az országok fejletlenebb régióinak az összevetésekor ugyanez a trend látszik: a vizsgált jólléti dimenziók esetében az egyes országok fejletlenebb periferikus térségeinek értékei szintén hasonlítanak egymásra.

A hasonlóság, vagy másképpen az egy időrendben lezajló közeledés mértékét a fejlettebb és a fejletlenebb régiók között csak további, differenciáltabb elemzésekkel, átfogó, empirikus kutatással lehet tisztázni.

\section{Jegyzetek}

1 A vizsgált régiók a következőek: Ausztria: Burgenland; Magyarország: Nyugati-dunántúli, Közép-dunántúli, Dél-dunántúli, Közép-magyarországi, Dél-alföldi, Észak-alföldi, Észak-magyarországi régiók; Románia: Nord Vest (Északnyugat-Románia), Vest (Nyugat-Románia), Centru (Közép-Románia); Szerbia: Vojvodina (Vajdaság); Szlovákia: Bratislavský kraj (Pozsonyi várostérség), Západné Slovensko (Nyugat-Szlovákia), Stredné Slovensko (Közép-Szlovákia), Východné Slovensko (Kelet-Szlovákia); Ukrajna: Zakarpattia Oblast (Kárpátalja).

2 A társadalmi jóllét stiglitzi fogalma nyolc tényezőt foglal magába: az anyagi életkörülményeket (ennek keretében a jövedelem, a fogyasztás és a vagyon mutatóit), az egészség, az oktatás, az egyéni aktivitások szempontjait (a munkát is beleértve), a politikai képviselet és a kormányzás, vagyis a politikai érdekérvényesítés mutatóit, a társadalmi és a személyes jellegű kapcsolatrendszerek összefüggéseit, a mai és a jövőbeni környezeti viszonyok és végül a gazdasági és a fizikai jellegű bizonytalanságok dimenzióit. Ezek közül ebben a tanulmányban a terjedelmi korlát miatt csak néhány, az adott tényezőt leginkább reprezentáló indikátort vizsgálunk (pl. iskolázottság: felsőfokú végzettségűek aránya; egészség: nők és férfiak születéskor várható élettartama).

3 Azoknál az ábráknál, ahol a trend hasonló az itt megadotthoz, csak hivatkozni fogunk erre az ábrára.

4 A deprivációs index kilenc mutatóból álló komplex jelzőszám. Azon társadalmi csoportoknak az arányát mutatja, akiknek anyagi problémáik vannak a következő területeken. 1. havi számlák kifizetése, 2. a lakás kifütése, 3. váratlan kiadások, 4. rendszeres hús-, hal-, gyümölcs-, zöldségfogyasztás, 5. egy hét nyaralás távol az otthontól, 6. személygépkocsi fenntartása, 7. mosógép nincs a lakásban, 8. színes tévé nincs a lakásban, 9. nem rendelkezik telefonnal.

5 Az emberi szegénységi mutatót (human poverty index) a HDI analógiájára dolgozta ki az ENSZ. Az index a szegénységet három indikátorból (születéskor várható élettartam, írástudatlanság és tiszta ivóvízhez való hozzájutás, valamint a korukhoz képest alacsony súlyú gyermekek száma) képzett komplex mutatóval ábrázolja.

6 A közmunkaprogram 2011 előtt is létezett Magyarországon, de más rendszerben, és a létszámadatok is erőteljesen növekedtek az elmúlt években. A jelenlegi rendszer sok kritikát kap, elsősorban azért, mert nem kínál valós alternatívát azoknak, akik tartósan kiestek a munkaerőpiacról, és ahelyett, hogy segítené őket visszatérni oda, konzerválja a szegénységet és a hátrányos helyzetűek kiszolgáltatottságát (Timár, Kovács, Váradi 2015). 


\section{Irodalom}

Berki, M., Halász, L. (2015): Social well-being in the Hungarian metropolitan regions: An empirical application of the Stiglitz Report. DETUROPE: Central European Journal of Tourism and Regional Development, 2., 233-257.

Blaskó Zs., Gödri I. (2016): A Magyarországról kivándorlók társadalmi és demográfiai összetétele. In: Blaskó Zs., Fazekas K. (szerk.): Munkaerőpiaci Tükör 2015. MTA KRTK KTI, Budapest, 59-68.

Credit Suisse (2014): Global wealth report 2014. Credit Suisse, Zurich http://www.nbr.co.nz/sites/ default/files/credit-suisse-global-wealth-report-2014.pdf (Letöltés: 2016. május 19.)

Dewsbury, R. (2012): Romania's population falls by $12 \%$ as 3 million flock to richer European countries including Britain. Mail Online, április 11.

Dogan, M. (2004): Introduction. Four hundred giant cities atop the world. International Social Science Journal, Mega-cities. 181., 347-361. http://doi.org/cm2njz

Gajdos, P. (2005): Regional development in Slovakia - developmental trends and social-spatial impact. Agricultural Economics, 6., 257-263.

Gajdos, P. (2008): Current state and development of regional disparities in Slovakia (with emphasis on underdeveloped regions). In: Gajdos, P. (2008): Regional disparities in Central Europe. Sociologiskyy ústav Slovenská Akadémia Vied, Bratislava, 98-116.

Enyedi, Gy. (2011): The stages of urban growth. In: Szirmai, V. (ed.): Urban sprawl in Europe: Similarities or differences? Aula, Budapest, 45-62.

Hárs Á. (2012): Munkapiaci válságok, változások. In: Kolosi T., Tóth I. Gy. (szerk.): Társadalmi Riport 2012. TÁRKI, Budapest, 159-190.

Horváth Gy. (2004): Regionális egyenlőtlenségek Európában. Magyar Tudomány, 9., 962-978.

Horváth, Gy. (2015a): Spaces and places in Central and Eastern Europe. Routledge, Oxford

Horváth Gy. (2015b): Kelet- és Közép-Európa régióinak portréi. Kossuth Kiadó, Budapest

Horváth Gy. (2015c): Életkörülmények eltérő adottságú kistérségekben (könyvszemle). Magyar Tudomány, 7., 893-896.

http://inequality.org/inequalityrelated-reports/ (Letöltés: 2016. május 11.)

InSerbia Network Foundation (2015): 2011 census of population: At least 313,411 Serbian citizens working abroad. április 24.

Karácsonyi, D., Mezentsev, K., Pidgrusnyi, G., Dövényi, Z. (2014): From global economic crisis to armed crisis: Changing regional inequalities in Ukraine. Regional Statistics, 2., 18-39. http://doi.org/brv9

Kiss É. (2015): Közvetlen külföldi tőkebefektetések a Kárpát-medencében. In: Fábián A. (szerk.): Otthon a Kárpát-medencében. Területfejlesztési Szabadegyetem 2011-2015. Nyugat-magyarországi Egyetem Kiadó, Sopron, 315-331.

Kolosi T. (2000): A terhes babapiskóta. A rendszerváltás társadalomszerkezete. Osiris, Budapest

Kolossov, V., Loughlin, J. O. (2004): How Moscow is becoming a capitalist mega-city. International Social Science Journal, 181., 413-429. http://doi.org/ctvhnx

Medgyesi M., Tóth I. Gy. (2012): A jövedelmi egyenlőtlenségek hosszú távú meghatározói Magyarországon. In: Kolosi T., Tóth I. Gy. (szerk.): Társadalmi Riport 2012. TÁRKI, Budapest, 19-39.

Mijačić, D., Paunović, B. (2011): Regional disparities in Serbia. Economica Preduzeća, 379-389.

Minarechová, R. (2015): Many Slovaks still migrate for work. The Slovak Spectator, május 18.

Osztálylétszám 2014 (2014): A magyar társadalom szerkezete. GfK, MTA TK, Budapest

Precupetu, I., Precupetu, M. (2013): Growing inequalities and their impacts in Romania. GINI Country Report, Romania. http://gini-research.org/system/uploads/441/original/Romania.pdf (Letöltés: 2016. július 2.)

Precupetu, I., Preoteasa, M., Vlase, I. (2015): Beyond poverty in Romania: An analysis of household. Sociológia, 3., 253-271.

Rosicova, K. et al. (2011): Regional socioeconomic indicators and ethnicity as predictors of regional infant mortality rate in Slovakia. International Journal of Public Health, 5., 523-531. http://doi.org/crdmxb

Schuchmann J., Váradi Zs. (2015): A magyar nagyváros-térségek társadalmi-demográfiai szerkezete. In: Szirmai V. (szerk.): A területi egyenlőtlenségektől a társadalmi jól-lét felé. KJF, Székesfehérvár, 111-131. 
Schuchmann J. (2015): Nagyváros-térségi szuburbanizációs folyamatok és költözési trendek. In: Szirmai V. (szerk.): A területi egyenlótlenségektól a társadalmi jól-lét felé. KJF, Székesfehérvár, 131-147.

Sik E., Szeitl B. (2016): Migrációs szándékok a mai Magyarországon. In: Blaskó Zs., Fazekas K. (szerk.): Munkaerőpiaci Tükör 2015. MTA KRTK KTI, Budapest, 54-59.

Stiglitz, J. E., Sen, A. Fitoussi, J. P. (2009): Report by the Commission on the Measurement of Economic Performance and Social Progress. Commission on the Measurement of Economic Performance and Social Progress, Paris

Stiglitz, J. E. (2012): The price of inequality: How today's divided society endangers our future. W.W. Norton, New York, London

Szirmai V. (szerk.) (2009): A várostérségi versenyképesség társadalmi tényezői. Hogyan lehetnek a magyar nagyvárosok versenyképesebbek? Dialóg Campus Kiadó, Pécs, Budapest

Szirmai V. (szerk.) (2015): A területi egyenlötlenségektól a társadalmi jól-lét felé. KJF, Székesfehérvár

Szivós P. (2014): A magyar háztartások jövedelme és fogyasztása nemzetközi összehasonlításban: felzárkózás vagy leszakadás? In: Kolosi, T., Tóth I. Gy. (szerk.): Társadalmi Riport. TÁRKI, Budapest, 51-63.

Timár J., Kovács K., Váradi M. M. (2015): Jól-lét deficit a hátrányos helyzetű kistérségekben. In: Szirmai V. (szerk.): A területi egyenlótlenségektől a társadalmi jól-lét felé. KJF, Székesfehérvár, 269-285.

Uzzoli A. (2006): A hazai egészségi állapot változásai 1990 után. In: A III. Magyar Földrajzi Konferencia tudományos közleményei. MTA Földrajztudományi Kutatóintézet, Budapest

Winkler, A. (2012): Measuring regional inequality: an index of socio-economic pressure for Serbia. Collection of Papers - Faculty of Geography at University of Belgrade, 60., 81-102.

Zsuppán, A. (2013): Why are so many Hungarians working in London? Budapest Telegraph, március 28. 